Chirurgia (2020) 115: 357-364

No. 3, May - June

Copyright@ Celsius

http://dx.doi.org/10.21614/chirurgia.115.3.357

\title{
Acute Colonic Pseudoobstruction (Ogilvie Syndrome) - A Severe Complication in the Evolution of the Hospitalized or Institutionalized Patients
}

\author{
Bogdan Socea', Simona Bobic ${ }^{2}$, Dan Nicolae Păduraru ${ }^{3}$, Alexandru C. Carâp ${ }^{1 *}$, Anca A. Nica', \\ Alexandru C. Smaranda ${ }^{2}$, Vladimir Ciobotaru', Cristiana Bogaciu², Ion Păun ${ }^{4}$, Ovidiu Gabriel Bratu ${ }^{5}$, \\ Cristinel D. Badiu ${ }^{6}$, Dragoș Predescu ${ }^{7}$, Vlad Denis Constantin ${ }^{1}$
}

${ }^{1}$ Carol Davila University of Medicine and Pharmacy, Surgery Department, "Sf. Pantelimon" Emergency Clinical Hospital, Bucharest, Romania ${ }^{2}$ Surgery Department, "Sf. Pantelimon" Emergency Clinical Hospital, Bucharest, Romania ${ }^{3}$ Carol Davila University of Medicine and Pharmacy, Surgery Department, Universitary Hospital of Bucharest, Romania ${ }^{4}$ University of Medicine and Pharmacy of Craiova, CF Craiova Clinical Hospital, Surgery Department, Craiova, Romania ${ }^{5}$ Carol Davila University of Medicine and Pharmacy, Urology Department, Central Clinical Military Hospital, Bucharest, Romania ${ }^{6}$ Carol Davila University of Medicine and Pharmacy, Surgery Department, Bagdasar-Arseni Emergency Clinical Hospital, Bucharest, Romania ${ }^{7}$ Carol Davila University of Medicine and Pharmacy, Surgery Department, Sf. Maria Clinical Hospital, Bucharest, Romania

${ }^{*}$ Corresponding author: Alexandru C. Carâp, MD Carol Davila University of Medicine and Pharmacy, Surgery Department, "Sf. Pantelimon" Emergency Clinical Hospital, Bucharest, Romania E-mail: alexandru.carap@umfcd.ro
Received: 26.09.2019 Accepted: 07.11.2020

\section{Rezumat}

Pseudo-obstrucția intestinală acută (sindromul Ogilvie) - o complicație severă în evoluția pacienților spitalizați sau instituționalizați

Introducere: Pseudo-obstrucția intestinală acută sau sindromul Ogilvie reprezintă o entitate patologică cu potențial letal, secundară dilatatiei masive colonice, în absența unei cauze obstructive mecanice. Apare, de obicei, în rândul pacienților spitalizați sau instituționalizați ce prezintă comorbidități severe medicale sau chirurgicale. Fiziopatologia pseudo-obstrucției intestinale acute nu este pe deplin cunoscută, însă, se presupune faptul că un dezechilibru al reglării autonome a funcției motorii colonice ar constitui principala cauză. Diagnosticul precoce şi instituirea rapidă a managementului terapeutic optim reprezintă principalele elemente ce scad riscul apariției complicaților severe de tipul ischemiei sau perforatiei colonice.

Material şi metodă: Pe lângă experiența noastră, a fost elaborat un studiu al literaturii recente de specialitate în scopul evaluării incidenței, etiologiei, tabloului clinic şi diagnosticului pseudoobstrucției intestinale acute.

Rezultate şi Concluzii: Scopul prezentului studiu este de a stabili algoritmul terapeutic optim pentru pacienții critici cu risc înalt de 
complicații de tipul pseudo-obstrucției intestinale acute, pe baza datelor publicate în literatura de specialitate.

Cuvinte cheie: Ogilvie, pseudo-obstrucție, colon

\begin{abstract}
Introduction: Ogilvie syndrome, or acute colonic pseudo-obstruction (ACPO), represents a pathological entity, potentially with a severe outcome, due to the acute important dilation of the large bowel, in the absence of a mechanical luminal obstruction. Usually, it occurs in patients admitted in intensive care unit, that associate severe surgical or medical pathologies. The mechanism of the ACPO has not been completely explained, but it is assumed that the motor function of the colon may be affected, as a result of autonomic regulation disturbance. Early diagnosis and treatment help reduce the risk of severe outcome, such as ischemia or perforation.

Material and method:In addition to our experience, a literature search was elaborated in order to evaluate the incidence, the etiology, the clinical presentation and the diagnosis of the ACPO.

Results and Conclusions: The present study may be of help in the process of guiding the optimal management of a critically ill patient is at high risk of developing colonic pseudo-obstruction.
\end{abstract}

Key words: Ogilvie, pseudo-obstruction, colon

\section{Introduction}

Acute colonic pseudo-obstruction (ACPO) was first described in 1948 by Sir William Heneage Ogilvie (1), as an important dilation of the large bowel, having non-specific symptoms. It presents clinical and radiological signs of acute occlusion without an identifiable obstacle (2). Several risk factors have been described in the etiology of the ACPO: neurological diseases, politrauma, sepsis, viral infections like SARS-CoV2, recent non-abdominal surgery (orthopedics, neurosurgery). The non-specificity of the clinical presentation in Ogilvie syndrome may lead to a delay in the diagnosis. An important step in the differential diagnosis process is to rule out the mechanical and other toxic causes of colonic paresis. The goal of the therapeutic management patients with ACPO is to evacuate the colon and lower the intraluminal pressure, thus minimizing risks of consecutive ischemia/necrosis and even perforation, complications known to associate high mortality rates (3). Supportive therapy, neostigmine administration in case of failure of medical treatment and colonoscopy for decompression represent the optimal first therapeutic steps, the surgical intervention being indicated only in those cases with peritonitis or perforation. Taking into consideration the relatively high incidence of the ACPO within the hospitalized or institutionalized cases, as shown by the results of the present study, it is imperative to implement early diagnostic and therapeutic protocols. The aim of the study is to evaluate the incidence, the risk factors and the optimal diagnostictherapeutic algorithm for Ogilvie syndrome, through a search of the recent international literature on the matter.

\section{Material and Method}

A systematic search of the Web of Science and Ovid HTTPS databases was performed from August 2009 to August 2019, using the search terms "Ogilvie's syndrome", "pseudoobstruction", and "pseudo obstruction". PubMed and Google Scholar were also searched using free text entries. The resulted articles were 
selected by title and abstract for inclusion, with subsequent acquisition of full texts. The reference lists of included papers were manually searched, and a hand search of the scientific literature was performed to identify additional relevant publications. Only the articles using English language were included in the present study. There were no exclusion limits by study design; both primary research and review articles were eligible. Full-text articles were evaluated for evidence addressing the definition, epidemiology, risk factors, aetiology and pathogenesis of ACPO. A narrative synthesis of the identified evidence was undertaken.

\section{RESULTS}

\section{Definition of $A C P O$}

ACPO is characterized by acute colonic dilatation in the absence of a mechanical or toxic cause of obstruction. Many overlapping terms have been used in order to describe ACPO, since its original description in 1948 by Sir William Heneage Ogilvie, thus demonstrating the uncertainty regarding its etiology (large intestine colic, Ogilvie's syndrome, pseudo-megacolon, adynamic ileus, paralytic ileus, functional obstruction of the intestinal tract, idiopathic large bowel obstruction, colonic ileus, etc.). The term "intestinal pseudo-obstruction" was first proposed by Dudley in 1958, with "ACPO" not appearing for another twenty years (1). Use of "Ogilvie's syndrome" has been discouraged due to ambiguity regarding its meaning, though considerable heterogeneity in terminology still exists in recent literature (1).

\section{Epidemiology of the ACPO}

The exact prevalence of ACPO is not well known, the highest prevalence being observed in late middle age (the sixth decade). Men are more affected compared to women (60\%) (4). It appears more frequent in admitted patients from normal wards or intensive care units, most of them having associated other medical conditions. It is observed in approximately $1 \%$ of patients after complex orthopedic interventions (like joint prosthesis, spinal interventions) (5). ACPO is an affection with poor prognosis, having important clinical and social consequences, increasing costs and time of hospitalization. Recent studies (6) have shown a high overall mortality rate of approximate $30 \%$ and increased even towards $50 \%$ when developing ischemia or perforation (3,7-9), that are directly correlated to associated illnesses, late diagnosis and inadequate treatment.

\section{Physiopathology}

The physiopathology of the ACPO is not completely understood, but it may be a result of an imbalanced regulation of the parasympathetic innervation of the colon, that increases contractility, versus the sympathetic one, that inhibits motility (10). Thus, a dysfunction of the autonomic regulation, secondary to multiple factors, may determine an augmentation of parasympathetic control or a sympathetic stimulation, resulting in a colic paresis (3).

Several metabolic syndromes (electrolyte imbalance, hepatic failure, renal failure), pharmacologic causes (anti-Parkinson drugs, anticholinergics, calcium channel blockers psychotropic drugs, epidural analgetics), traumatic factors (complex surgical interventions, infections), cardiac/neurological diseases, sepsis, viral infections (like SARS-CoV-2) are implicated in the autonomic adjustment of colic mobility, leading to pseudo-obstruction. $(3,10)$. A retrospective study of 400 patients having Ogilvie syndrome, showed that the most frequent associated conditions were: surgical interventions, non-operative trauma, infections, heart diseases (3), with Cesarean section and hip surgery being the most common surgical procedures.

\section{Diagnosis}

Abdominal distension represents a constant clinical finding, present in almost all patients with ACPO (3). Abdominal meteorism usually 
appears in the first 3-7 days, but can develop even more rapid, in the first 24-48 hours. Other frequently encountered findings are represented by nausea/vomiting (60\% cases), high temperature, constipation or, paradoxically, diarrhea. Dyspnea may be present in these patients, as a consequence of the important distention of the abdomen $(1,3,4)$. The clinical examination may reveal a tympanic abdomen on percussion, high-pitched 'tinkling' or reduced/absent bowel sounds on auscultation. It has been observed that it is difficult to distinguish patients with bowel ischemia and perforation from those presenting only important, but uncomplicated abdominal distension. Peritoneal signs and fever can make the difference (10). Thus, the suspicion for this syndrome must remain high in all cases of colonic distension, and the use of diagnostic tests is essential for early detection. For operated patients, signs and symptoms usually occur in the first 5 postoperative days.

The diagnostic of Ogilvie syndrome is often clinically suggested. Its confirmation comes from the plain abdominal radiography, that shows dilatations of the colon and small bowel and sometimes even air fluid levels. The most dilated areas are usually located at the level of caecum and the ascending colon, commonly till the splenic flexure or the descending colon. This pathological distribution of dilatations seems to be related to different territories innervated by the parasympathetic autonomic system from different origins. The presence of pneumoperitoneum and pneumatosis must be assessed.

The main differential diagnostic of Ogilvie syndrome should be made with bowel occlusion of mechanical cause $(11,12)$. Other conditions that should be excluded, are: paraneoplastic syndromes (13), inflammatory bowel diseases $(14,15)$, Clostridium difficile or other colonic infections with toxic megacolon (16), retroperitoneal tumors (17). Watersoluble contrast enema radiography $(96 \%$ sensitivity and $98 \%$ specificity (18)), or computed tomography (CT with both sensitivity and specificity of 91\% (19)) may differentiate the mechanical obstruction from pseudo-obstruction. On CT sections, we can accurately measure the diameter of the colon and a fare evaluation of the inflammation and mucosal state can be done by wall measurements. Wall thickening, submucosal oedema and intramural gas are relevant for ischaemic changes of the mucosa with/without advancing necrosis. The endoscopic evaluation of the colon may split Ogilvie syndrome from obstruction causes. Although, colonoscopy is not the best method for these causes because of perforative risks.

\section{Therapeutical Management}

The essential steps in the management of ACPO are represented by early recognition and diagnosis, excluding mechanical obstruction or any other causes of ileus, evaluation of signs that could early detect ischemia or perforation, that urgently impose a surgical attitude.

Therapeutic management is oriented by colonic distention and the vascularisationof the bowel. Fig. 1 shows a proposed plan for the therapeutic management of Oglivie syndrome, according to the American Society of Colon and Rectal Surgeons (ASCRS) (10).

Spontaneous colonic perforation appears in about $3 \%$ patients with ACPO (9), increasing in case of a cecal diameter greater than $12 \mathrm{~cm}$ (other studies indicate a $14 \mathrm{~cm}$ diameter) and a duration of distension of more than 6 days. There are no clear evidences regarding the degree of cecal distentions and its duration. Any cecal distension, greater than $10 \mathrm{~cm}$, that last for more than 72 hours is considered to have high risks of ischemia and perforation (Fig. 1).

The recommended management for Ogilvie syndrome in non-complicated cases, and no imminence of cecal perforation remains conservative therapy: hydroelectrolyte rebalancing (especially treatment of hypokalemia and hypomagnesaemia), fluid resuscitation, avoidance or minimization of drugs administration that delay intestinal movements (anticholinergic drugs, opiates, calcium ionic channels blockers), 
Figure 1. Therapeutical algorithm for ACPO, according to the American Society of Colon and Rectal Surgeons (ASCRS)

\section{Signs of intestinal occlusion}

Excluding the mecanical/toxic cause of obstruction

\section{ACPO}

\section{Ischemia/perforation}

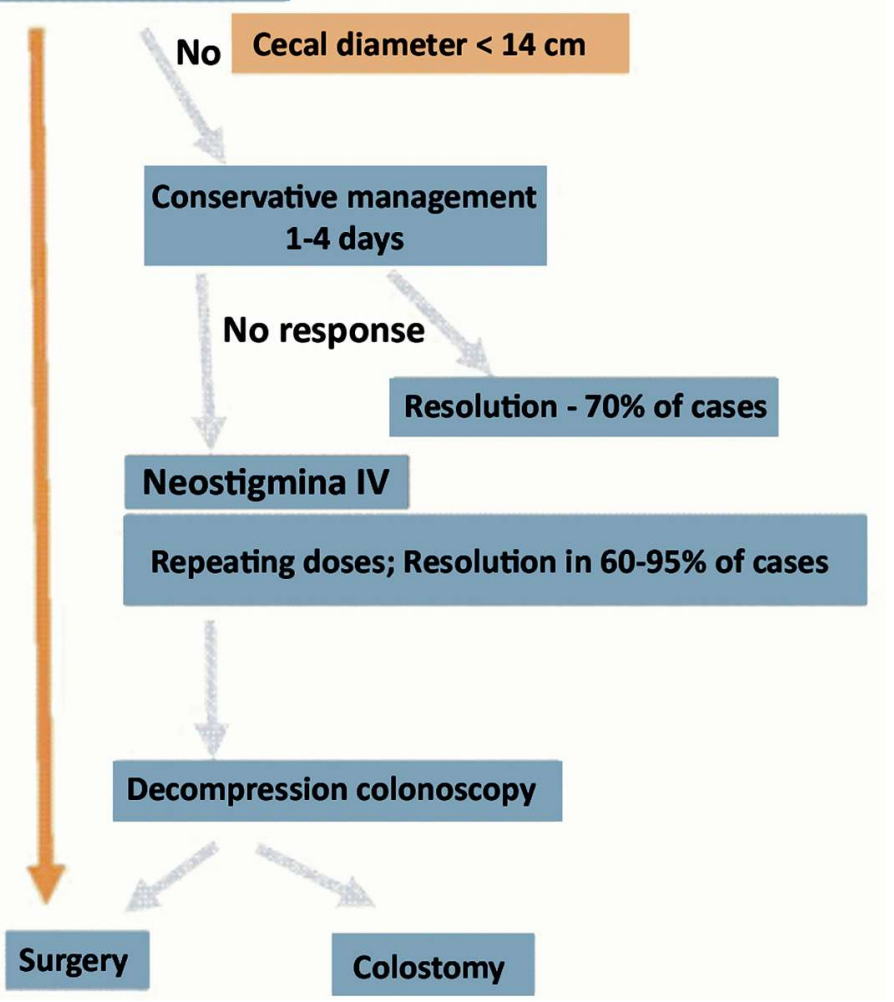

treatment of eventual concomitant infections, bowel rest, ambulation. Prone positioning is recommended to facilitate gas colic eliminations by abdominal increasing pressure, and naso-gastric tube insertion or rectal gas tube facilitates stomach, respectively colon decompression. For colonic ileum and gas dilation, nor oral osmotic substances, nor irritant laxatives, are recommended. All these could even due to supplementary gas production and propulsion into an already dilated colon, determining an unwanted event of worsening colonic dilation $(3,4)$. In order to detect in the early phases the ischemia or peforation, we should do regularly clinical examinations of the patients and check abdominal radiography without contrast. Clinical findings of bowel ischemia could be: pain, abdominal tenderness or guarding, sepsis signs, fever, raised $\mathrm{C}$ reactive protein, high white blood count. If there are no clinical, nor paraclinical signs of colon ischemia, perforation, or imminence of perforation, the conservative measures are recommended for the first 48-72 hour. This will lead to clinical remission in approximately $70 \%-90 \%$ cases of patients with ACPO (3).

If there are no signs of ischemia or perforation and no response to the conservative management, drug treatment - Neostigmine intravenously administered (IV) - should is the golden standard initial therapy (Table 1).

The mechanism of action for neostigmine involves inhibition of acetylcholinesterase. Being an enzyme that catalyzes the break- 
Table 1. Medical treatment with Neostigmin in patients with ACPO (inspired from (10))

\begin{tabular}{ll}
\hline First line therapy & $\begin{array}{l}\text { Neostigmin 2-2,5mg administered intravenously over 3-5minutes. } \\
\text { Repeating dose for max } 3 \text { times, in initial non-responders or partial responders } \\
\text { within the first } 3 \text { hours }\end{array}$ \\
\hline Salvation therapy & $\begin{array}{l}\text { Neostigmin } 0,4-0,8 \mathrm{mg} \text { per hour perfusion/ 24hours } \\
\text { or } \\
\end{array}$ \\
& Piridostigmin $10-30 \mathrm{mg}$ orally, twice a day \\
\hline Adjuvant therapy & $29,5 \mathrm{~g}$ Polietilen-glicol in $500 \mathrm{ml}$ water, orally, twice a day \\
\hline For ileus secondary & Metilnaltrezone $12 \mathrm{mg}$ subcutaneous - at24/48 hours \\
to opiates administration &
\end{tabular}

down of acetylcholine, the drug increases the level of acetylcholine in the parasympathetic synapses that will bind to receptors. The colonic effect of acetylcholine translates into the stimulation of peristalsis. Through this effect, neostigmine has been shown to reduce large bowel dilation in approximately $90 \%$ of cases of ACPO, as demonstrated in 3 Placebo- $^{-}$ controlled, prospective randomized trials (20).

Administration of $2 \mathrm{mg}$ of neostigmine, intravenously in 3-5 minutes, results in a rapid clinical response - on average in 4 minutes (between 3 and 30 minutes) -, consisting of resumption of peristalsis and emptying of the colon. In patients who do not respond to the first doze, another one may be given after an interval that ensures the metabolism of first neostigmine dose (above the half-life time, that is 80 minutes). This second dose is effective in $40 \%$ to $100 \%$ of them (21).

The use of neostigmine is associated with several important side effects, such as bronchospasm, hypotension, bradycardia and even syncope. Therefore, the administration is done only under strict monitoring of blood pressure, pulse and electrocardiographic line. Cases of severe bradycardia usually respond to atropine. The risks are higher in case of bolus administration of a high or complete dose. Therefore, it is recommended that the initial dose should not exceed $1 \mathrm{mg}$, or that the administration should be slow (continuous intravenous perfusion of $0,4-0,8 \mathrm{mg}$ neostigmine per hour, over 24h) (21). Absolute contraindications are represented by the appearance of colonic perforation, pregnancy, cardiac arrhythmias, bronchospasm, while relative contraindications are: recent bowel perforation, perforated peptic ulcer, cardiac ischemia, beta-blockers consume, chronic obstructive pulmonary disease, asthma, renal failure (creatinine above $3 \mathrm{mg} / \mathrm{d}$ ). For bradycardic patients, patients with renal failure, asthma or chronic obstructive pulmonary disease, recent myocardial infarctisation, neostigmine can only be administered with special precautions.

Colonoscopic decompression is indicated in extreme cases, with important dilatation of the large bowel, that do not respond to neostigmine and conservative treatment, or when there is a contraindication for the administration of neostigmine (Fig. 1). Recent studies have demonstrated an efficiency of $61 \%$ to $95 \%$ in initial colon decompression, and of $70 \%$ to $90 \%$ in case of sustained decompression $(3,20)$. Most of the times, the colonoscopic decompression procedure needs to be repeated periodically as many times as necessary, as well as the installation of the intraanal gas decompression tube.

Surgical therapy is recommended only for complicated disease, with colic ischemia and perforation or for the patients that not respond to neostigmine and colonoscopic decompression. The results of the recently published literature showed a 10\% rate of persistent colon dilation refractory to nonoperative measures $(10,22)$.

The main disadvantages of the surgical management are represented by the high morbidity and mortality rates, possibly in relation with severe co-morbidities. 


\section{Discussion}

The present article highlights the fact that the mechanisms involved in the physiopathology of the ACPO still remain uncertain. There are limited physiological evidence from patients with ACPO and the lack of proper animal models has required extrapolation of data from other disease studies. Multiple risk factors and associated conditions have been identified, thus supporting a multifactorial hypothesis in the physiopathology of the ACPO. It has been shown by multiple recent studies that the autonomic imbalance of the colon plays a key role in the development of the Ogilvie syndrome, an idea that can be sustained by the sudden transition point from distended to normal colon in ACPO usually occuring at the splenic flexure, this anatomic site corresponding to the change in autonomic innervation of the mid-gut and hind-gut. However, the precise mechanism involved in the autonomic function leading to ACPO remains unclear.

ACPO still represents a pathological entity difficult ti investigate due to its acute and sporadic nature and heterogeneity. The large number of case reports, in contrast with the limited number of case series or cohort studies identified in the literature, is testament to the large number of illnesses associated with this condition and to the absence of a clear definition of ACPO. It can be deduced that there is no categorical clinical description of the ACPO because there islimited evidence investigating the mechanisms underlying this condition.

A number of areas for further study have been identified, that include the development of an animal model of ACPO, histological examination of resected specimens, and rigorous investigation of the impact of preventative or therapeutic strategies on colonic function.

It is hoped that an improved understanding of the pathophysiology of ACPO will lead to the development of targeted strategies for its prevention and treatment.

\section{Conclusions}

- Ogilvie's syndrome represents an abdominal distension syndrome, without any evidence of mechanical occlusion of the lumen.

- Diagnosis is established by plain abdominal radiography and computed tomography scan.

- Early and adequate treatment is a key factor in the evolution of the patients with ACPO that allows a lowered risk of complications.

- The initial recommended treatment is conservative: digestive rest, correction of hydroelectrolytic disorders and cessation of medication that may aggravate ileus.

- If no improvement is observed in the first 24-48 hours of conservative management, Neostigmine administration should be initiated, in the absence of contraindications.

- Endoscopic decompression is reserved only for those patients that do not respond to neostigmine.

- All cases with peritoneal irritation produced by a colonic perforation should required urgent surgical intervention.

- Other areas for future pathophysiological investigation include the development of an animal model of ACPO, histological examination of resected specimens, and rigorous investigation of the impact of preventative or therapeutic strategies on colonic function

- It is also clear that a categorical clinical definition of ACPO is needed to standardize research, and improve the quality of published evidence.

\section{Author's Contributions}

All authors equally contributed to this manuscript.

\section{Conflict of Interest}

The authors declare no conflicts of interests. 


\section{References}

1. Ogilvie WH. Large intestine colic due to sympathetic deprivation: A new clinical syndrome. BMJ. 1948;2:671-673.

2. Coulie B, Camilleri M. Intestinal pseudo-obstruction. Annu Rev Med. 1999;50:37-55.

3. Vanek VW, AL-SALTI M. Acute pseudo-obstruction of the colon (Ogilvie's syndrome). An analysis of 400 cases. Dis Colon Rectum. 1986;29:203-210.

4. Georgescu S, Dubei L, Zaharia M, Cîrdei C, Crumpei F, CijevschiPrelipcean C, et al. Ogilvie's syndrome - acute colonic pseudoobstruction. Case report and review of the literature. Rom $J$ Gastroenterol. 2003;12(1):51-5.

5. Norwood MG, Lykostratis H. Garcea G, Berry DP. Acute colonic pseudoobstruction following major orthopaedic surgery. Colorecta Dis. 2005;7:496-499.

6. Batke M, Cappell MS. Adynamic ileus and acute colonic pseudoobstruction. Med Clin North Am. 2008;92:649-670, ix.

7. Woywodt A, Matteson E. Should eponyms be abandoned? Yes. BMJ. 2007;335:424

8. Geelhoed GW. Colonic pseudo-obstruction in surgical patients. Am J Surg. 1985;149:258-265.

9. Wegener M, Borsch G. Acute colonic pseudo-obstruction (Ogilvie's syndrome). Presentation of 14 of our own cases and analysis of 1027 cases. Surg Endosc. 1987;1(3):169-74.

10. Vogel J, Feingold D, Stewart DB, Turner JS, Boutros M, Chun J, et al. Clinical practice guidelines for colon volvulus and acute colonic pseudo-obstruction. Dis Colon Rectum. 2016;59:589-600.

11. Tulin A, Nitipir C, Slavu I, Braga V, Mihaila D, Alecu L. Watch and Wait Strategy for Rectal Cancer: 15 Years After the First Published Study. Are We any Closer to the Non-operative Management of Rectal Cancer? Chirurgia (Bucur). 2019;114(2):174-178.

12. Paun I, Constantin VD, Socea B, Bobic S. The impact of environmental factors upon the incidence rate of colorectal cancer. Ciencia e Tecnica Vitivinicola, 2015;30/2(11):99-133.

13. Draghici T, Negreanu L, Bratu OG, Pantea Stoian A, Neagu TP, et al. Paraneoplastic syndromes in digestive tumors: a review. Romanian Biotechnological Letters. 2018;23(6):1-10.

14. Slavu I, Tulin A, Alecu L, Mihaila D, Braga V, Voiosu T, et al. Clinical Pattern of Surgical Crohn Disease Patients. Chirurgia (Bucur). 2018;113(4):497-502

15. Slavu I, Alecu L, Tulin A, Mihaila D, Braga V, VoiosuT, et al. Reintervention Rate Following Emergency Surgery for Crohn Disease. Chirurgia (Bucur). 2018;113(2):227-233.

16. Socea B, Halau O, Diaconu C, Bratu OG, Neagu TP, Dimitriu M, Constantin VD. Clostridium difficile infections in surgical patients (literature review). Romanian Journal of Medical Practice. 2019; XIV(1):30-33

17. Bratu OG, Marcu RD, Socea B, Neagu TP, Diaconu CC, Scarneciu I, et al. Immunohistochemistry particularities of retroperitoneal tumors. Rev. Chim. (Bucharest), 2018;69(7):1813-6

18. Chapman AH, McNamara M, Porter G. The acute contrast enema in suspected large bowel obstruction: value and technique. Clin Radiol. 1992;46:273-278.

19. Godfrey EM, Addley HC, Shaw AS. The use of computed tomography in the detection and characterisation of large bowel obstruction. N Z Med J. 2009;122(1305):57-73.

20. Van der Spoel JI, Oudemans-Van Straaten HM, Stoutenbeek CP, Bosman RJ, Zandstra DF. Neostigmine resolves critical illnessrelated colonic ileus in intensive care patients with multiple organ failure: a prospective, doubleblind, placebo-controlled trial. Intensive Care Med. 2001;27:822-827.

21. White L, Sandhu G. Continuous neostigmine infusion versus bolusneostigmine in refractory Ogilvie syndrome. Am J Emerg Med. 2011;29:576.e1-576.e3.

22. Geller A, Petersen BT, Gostout CJ. Endoscopic decompression for acute colonic pseudo-obstruction. Gastrointest Endosc. 1996;44: 144-150. 